\title{
New Developments in Quantitative Real-time Polymerase Chain Reaction Technology
}

\author{
http://dx.doi.org/10.21775/cimb.016.001
}

\author{
Vijay J. Gadkar and Martin Filion* \\ Department of Biology, Université de Moncton, \\ 18 Antonine-Maillet, Moncton, NB E1A 3E9 Canada
}

\begin{abstract}
Real time-quantitative PCR (RT-qPCR) technology has revolutionized the detection landscape in every area of molecular biology. The fundamental basis of this technology has remained unchanged since its inception, however various modifications have enhanced the overall performance of this highly versatile technology. These improvements have ranged from changes in the individual components of the enzymatic reaction cocktail (polymerizing enzymes, reaction buffers, probes, etc.) to the detection system itself (instrumentation, software, etc.). The RTqPCR technology currently available to researchers is more sensitive, faster and affordable than when this technology was first introduced. In this article, we summarize the developments of the last few years in RT-qPCR technology and nucleic acid amplification.
\end{abstract}

\section{Introduction}

Since its introduction in the late 1990s, real time-quantitative PCR (RT-qPCR) technology has revolutionized the detection landscape in every aspect of molecular biology (Filion, 2012). The fundamental basis of this technology has remained unchanged since its inception, which is fluorescence based detection of its target, amplified via classical multistep PCR. A steady modification(s) of individual components which makeup the RT-qPCR platform has however enhanced the overall performance of this highly versatile technology. These improvements have ranged from changes in the individual components of the enzymatic reaction cocktail (polymerizing enzymes, reaction buffers, probes, etc.) to the detection system itself (instrumentation, software, etc.). As a result, the RT-qPCR technology currently available to researchers is more sensitive, faster and most importantly, affordable for laboratories on moderate/modest budgets, than when this technology was first introduced (Filion, 2012).

In this article, we seek to briefly summarize some of the developments which have happen within the last few years in the area of RT-qPCR technology and nucleic acid amplification (e.g. classical PCR). In our opinion, these developments might have a direct relevance for researchers working in the area of environmental transcriptomics. Some of described examples in this article have been validated on RT-qPCR platforms, making it relatively easy to adapt in their current state, while others have only been implemented on a conventional end-point detection platform.

\footnotetext{
${ }^{*}$ Corresponding author: Email: martin.filion@umoncton.ca
}

\section{Isothermal detection methods}

The current RT-qPCR technology is based on the classical three-step thermal cycling process which is, template denaturation, followed by primer/probe annealing and finally, extension/detection of the fluorescence signal, to amplify and detect the target transcripts all under real-time conditions (Gelfand, 1992). A very commonly observed phenomenon in this multistep thermo-cycling amplification system is the generation of spurious fluorescence signal due to mispriming of primer/probes. To overcome such limitations, detection platforms have been proposed which amplify the target exponentially like PCR, but under isothermal conditions, i.e. at a fixed, user-defined temperature (reviewed by Gill and Ghaemi, 2008).

The helicase-dependent (HDA) amplification system is one such novel 'non-PCR' system for amplifying target DNA (Vincent et al., 2004) and RNA (Goldmeyer et al., 2007), under isothermal conditions. This revolutionary amplification system makes use of a novel enzymatic cocktail which does not require the DNA to be cycled between different temperatures, like that done for reactions based on Taq DNA polymerase amplification or any of its variants. In lieu of a standard denaturation step, the HDA system uses the helicase enzyme to unwind the double-stranded DNA and with the aid of other polymerizing enzymes, an exponential amplification is achieved (Vincent et al., 2004). All these steps are performed at a fixed, user defined temperature. Though extremely novel when first introduced, the HDA system suffers from one major limitation- its inability to amplify DNA targets greater than $200 \mathrm{bp}$ (Vincent et al., 2004). As a result, in its present state, it is seriously unable to challenge and act as a viable alternative to the highly versatile PCR, or any amplification system based on it.

Despite this technical limitation, HDA-based amplification is increasingly being viewed as an attractive alternative in any amplification system, where length of the amplicon is less than $200 \mathrm{bp}$. One excellent example of such short amplicon size detection system is RT-qPCR. It is a well known fact that, for an efficient amplification, the primer/probe parameters of the RT-qPCR detection system is usually within the $50-150 \mathrm{bp}$ size range. It is therefore not impossible to develop a RT-qHDA detection system, where the classical Taq DNA polymerase amplification cocktail is substituted by an enzymatic system, which amplifies its target at a fixed (isothermal) temperature.

Recently, Tong et al. (2008) showed that such enzymatic substitution is indeed feasible. In their work, primer/probes designed for TaqMan RT-qPCR fluorescence system were used to develop a novel RT-qHDA system to detect various biothreat microorganisms. Since pre-existing TaqMan primer/probes were used, the RT-qHDA system was optimized to work with the $60-65^{\circ} \mathrm{C}$ temperature range and detection sensitivity, similar to what one would 
expect from a classical RT-qPCR system. Though very preliminary, it is tempting to conclude that the RT-qHDA system, at least in theory, is 'backward compatible' with a pre-existing RT-qPCR system. In other words, the user does not have to separately invest in a new detection platform (i.e. instrumentation) or custom synthesize the flurogenic probes, both of which could be prohibitively expensive. The only modification one would have to make is to substitute the Taq DNA polymerase based reaction components, with a HDA amplification cocktail, which is now commercially available in various formats from Biohelix Corp, USA. Interestingly enough, isothermal amplification systems themselves are also constantly being refined to enhance fidelity (amplicon length) and robustness of the amplification process. Protocols which make use of novel enzymatic cocktails which are more efficient in unwinding and amplifying the target double helix are constantly being reported (Kiesling et al., 2007; Tan et al., 2008; Schaerli et al., 2010; Joneja and Huang, 2011).

In our opinion, adapting such 'non-PCR' amplification technologies could in the near future lead to detection platforms (Mahalanabis et al., 2010) which are more robust and would not suffer from the inherent drawbacks, for example spurious amplification, cycling parameter standardization, typically associated with the classical three-stage PCR system.

\section{Development of novel normalization controls}

The first step towards analysing microbial gene expression requires a quantitative extraction of RNA. This step has proven to be highly problematic for environmental matrices, due to compounded inefficiencies in individual steps which include, but not limited to, incomplete cell lysis, RNA degradation by ubiquitous RNases, co-extraction of inhibitors and their interaction with the enzymes used (Lorenz and Wackernagel, 1987; Moran et al., 1993, Alm and Stahl, 2000). One straightforward approach to quantify such losses and apply the necessary correction is to include an internal amplification control (IAC), so as to make the final gene expression meaningful and reproducible. An IAC is essentially a non-target DNA/RNA sequence co-amplified, preferably in the same reaction tube, under the same reaction conditions (Hoorfar et al., 2003, 2004; Nolte, 2004; van Doorn et al., 2009). While attempts to develop IAC's have met with some success for experimental systems which are highly controlled (Oikonomou et al., 2008; Scipioni et al., 2008), developing such controls have proven to be highly problematic for certain experimental set-ups, for example complex environmental matrices. The main difficulty in these cases has been in our inability to identify an inert IAC which is able to (a) withstand the harsh nucleic acid extraction procedures usually employed for environmental matrices, and if such a sequence is indeed developed/ identified (b) designing a primer/probe combination which would not cross-react with other non-target (nucleic acids) components of the matrices. While few potential IAC based solutions have been proposed, for example the Biotrove OpenArray platform (van Doorn et al., 2009), high costs and proprietary issues of some IAC sequences (Nordstrom et al., 2007) have served as a deterrent for researchers who are seriously interested in rigorously implementing this external normalization strategy.

Recently, Gonzalez-Escalona et al. (2009) proposed the implementation of a highly versatile RNA based IAC, called the mylC system. The mylC is essentially a $200 \mathrm{bp}$ artificial sequence, with no known homology to any nucleic acid accession in the GENBANK (NCBI) database. As a result, primer/probes designed for this sequence are not expected to cross-react with any non-target nucleic acids, typically expected to be present in high amounts in RNA/ DNA extracted from complex environmental matrices. Recently, its applicability was successfully demonstrated in quantifying bacterial gene transcripts from natural soil samples spiked with a defined amount of the bacterium Pseudomonas sp. LBUM300 (DeCoste et al., 2011). This success should spur researchers to implement the mylC system to quantify microbial gene expression in other environmental matrices, but were unable due to lack of a suitable IAC. The added advantage of its non-proprietary usage and its applicability in both DNA/RNA formats (Gonzalez-Escalona et al., 2009; Deer et al., 2010), makes mylC a very attractive IAC to implement in various RTqPCR based detection systems.

\section{LNA/Zip nucleic acids}

One critical factor for any PCR based detection platform, including RT-qPCR, is the invariant ability of the primer/ probe to discern its target from a heterogeneous mixture and bind it with extreme specificity. In RT-qPCR, the design of these primers/probes is governed by strict guidelines (hybridization/sequence parameters) which, in turn, are based on the fluorescence chemistry used for that particular assay. For example, the hybridization parameters for TaqMan assays are different from the Molecular beacon based flurogenic assays. Empirically, these primers/probes are designed with the help of specific software's (e.g. PrimerExpress ${ }^{\mathrm{TM}}$ for TaqMan detection system) which are proprietary and usually supplied with the detection platform. Since these software use specific built-in algorithms, with a narrow set of highly defined binding parameters, it is not very uncommon to find these design software unable to identify optimal primer/probe combinations for a particular user input sequence.

While these design limitations have not exactly impeded our ability to vigorously implement the RT-qPCR technique, there has always been an ongoing endeavour to increase the sensitivity of an assay by enhancing the 'specificity and recognition' capacity of a primer/probe. The most conventional approach to achieve this goal has been to manipulate various components of the amplification reaction, for example use of reaction buffer which are highly optimized, increased level of divalent ions $\left(\mathrm{Mg}^{2+}\right)$ and use of specific additives which are known to prevent primer mispriming. Early research has however showed that it is also possible to enhance the specificity and recognition aspects of an oligonucleotide, by another novel approachchemical modification of the oligonucleotide backbone itself. As a result of this modification, the oligonucleotide is able to bind to its target with extreme specificity and enhanced accuracy.

Of the several modifications developed till date (Hyrup and Neilson, 1996; Schulz and Gryaznov, 1996; VanAerschot et al., 1996; Hendrix et al., 1997; Nielson and Haaima, 1997), the locked nucleic acids (LNA) are probably seen as the most promising in terms of design simplicity and superior functionality, i.e. its unique ability to recognize 
and bind to its target with an extreme precision (Obika et al., 1998; Singh et al., 1998). The high specificity of LNAs have made it possible to apply it in single-nucleotide polymorphism (SNP) genotyping and detection of difficult templates which, otherwise is not feasible with conventional primer/probes (Simeonov and Nikiforov, 2002; Latorra et al., 2003; Johnson et al., 2004; Ugozzoli et al., 2004). The recent introduction of zip nucleic acids (ZNA), which have similar functional properties of LNAs but, based on a different modification chemistry (Voirin et al., 2007), is also an exciting development. The ZNA oligonucleotides have a spermine residues conjugated to the basic oligonucleotide backbone. This modification results in reduced electrostatic repulsion brought about by the polyanionic nature of nucleic acids. As a result, an enhanced sensitivity is routinely observed in detecting its target during both RT-qPCR and reverse transcription assay (Moreau et al., 2009).

In our opinion, these 'enhanced specificity' oligonucleotides like LNAs, could be further exploited to design RT-qPCR primer/probes used to detect microbial gene expression from environmental matrices, especially complex types. As analysing gene expression from environmental samples entails discerning the target from a heterogeneous background, an enhanced specificity primer/ probe would result in a very high signal-to-noise ratio and hence a more robust, accurate and reproducible detection of the target transcripts. The commercial availability of both the LNA and ZIP oligonucleotides should make it easier for researchers to develop specific applications to accurately detect its target from environmental matrices.

\section{Use of polymerases engineered to resist inhibitors}

As gene expression analysis using RT-qPCR entails the synthesis of cDNA by the reverse transcriptase (RT) enzyme, followed by an exponential amplification of the template by DNA polymerase, any chemical moiety, which is able to alter the fidelity (negatively) of these enzymes, has a direct bearing on the end results (Suslov and Steindler, 2005). The net effect of such interferences, at least in RT-qPCR, is the invariable quenching of the fluorescent signal, leading to sub-optimal or irreproducible gene expression data. Consequently, solutions are constantly being sought which could in some way, alleviate the effects of these interfering moieties on the normal functioning of these enzymes. Some of the commonly used inhibitor mitigation strategies include, use of RNA exaction protocols specifically designed to eliminate co-extracted inhibitors, and addition of specific additives in the RT-qPCR reaction which are known to bind the inhibitor moieties (e.g. BSA, T4 gene 32 protein). One attractive solution which could be an 'add-on' to these aforementioned solutions is the use of enzymes (reverse transcriptase and DNA polymerase enzymes) which are inherently 'resistant' to any of the signal quenching inhibitors.

The first step in RT-qPCR based gene expression analysis is the faithful conversion of RNA to CDNA by reverse transcription. Therefore, the first step would be the development of an RT enzyme which is able to resist a wide spectrum or a specific class of environmental inhibitors. While most RTs are highly sensitive to inhibitors, the recent report of a mutant Moloney murine leukaemia virus (MMLV)-RT enzyme, resistant to few common known inhibitors (Arezi et al., 2010), is an exciting development. In the second step of RT-qPCR, the DNA polymerases are the most important component used for the exponential amplification of the target. While certain variants of DNA polymerases are capable of tolerating chemical inhibitors up to certain extent (Al-Soud and Rådström, 1998), the development of a DNA polymerase specifically engineered to resist inhibitors, has not been attempted till recently. Kermekchiev et al. (2009) using a site directed mutagenesis strategy, whereby a 'designer' DNA polymerase capable of resisting two recalcitrant inhibitors namely humic/fulvic acid (commonly found in soil) and haemoglobin (common in meat based matrices) was developed. Recently, Baar et al. (2011) showed through molecular breeding, development of a novel DNA polymerase called 2D9, which has sequence elements from four different DNA polymerases. This 'chimeric' polymerase exhibits a striking resistance to a broad spectrum of complex inhibitors including humic acid, bone dust, coprolite, peat extract, clay-rich soil, cave sediment and tar.

Taking both these development into consideration, it could be possible in the near future to develop RT-qPCR protocols which are specifically tailored for environmental microbiology. This modified approach would allow the end user to perform a more reproducible detection and quantification of gene expression from environmental matrices. Commercial availability, unit cost and proprietary issues are some of the factors which one would have to consider prior to implementing this approach.

\section{Conclusion}

The application of the RT-qPCR technology has contributed immensely to our understanding of gene expression in various biological systems; however in certain areas of research, for example applied microbiology, application of this technique has not progressed as one would have liked to expect. This application gap could at best be attributed to the extreme difficulties in extracting nucleic acids from environmental samples and the high sensitivity of the RTqPCR system towards chemical components inherently coextracted from environmental samples. Development of a more robust RT-qPCR platform is one possible solution to overcome this problem. We believe that a cross-adaption of some new developments in amplification and enzymatic technology would alleviate some of the drawbacks inherent to the RT-qPCR technology so that it's potentially is fully realized in areas like applied microbiology (Filion, 2012).

\section{References}

Alm, E.W., and Stahl, D.A. (2000). Critical factors influencing the recovery and integrity of rRNA extracted from environmental samples: use of an optimized protocol to measure depth-related biomass distribution in freshwater sediments. J. Microbiol. Methods 40, 153-162.

Al-Soud, W.A., and Rådström, P. (1998). Capacity of nine thermostable DNA polymerases to mediate DNA amplification in the presence of PCR-inhibiting samples. Appl. Environ. Microbiol. 64, 3748-3753.

Arezi, B., McCarthy, M., and Hogrefe, H. (2010). Mutant of Moloney murine leukemia virus reverse transcriptase exhibits higher resistance to common RT-qPCR inhibitors. Anal. Biochem. 400, 301-303.

Baar, C., d'Abbadie, M., Vaisman, A., Arana, M.E., Hofreiter, M., Woodgate, R., Kunkel, T.A., and Holliger, P. (2011). Molecular breeding of polymerases for resistance to 
environmental inhibitors. Nucleic Acids Res. 39, e51.

DeCoste, N.J., Gadkar, V.J., and Filion, M. (2011). Relative and absolute quantitative real-time PCR-based quantifications of $h c n C$ and $p h I D$ gene transcripts in natural soil spiked with Pseudomonas sp. strain LBUM300. Appl. Environ. Microbiol. 77, 41-47.

Deer, D.M., Lampel, K.A., and González-Escalona, N. (2010). A versatile internal control for use as DNA in realtime PCR and as RNA in real-time reverse transcription PCR assays. Lett. Appl. Microbiol. 50, 366-372.

van Doorn, R., Klerks, M.M., van Gent-Pelzer, M.P., Speksnijder, A.G., Kowalchuk, G.A., and Schoen, C.D. (2009). Accurate quantification of microorganisms in PCR-inhibiting environmental DNA extracts by a novel internal amplification control approach using Biotrove OpenArrays. Appl. Environ. Microbiol. 75, 7253-7260.

Filion, M. (2012). Quantitative Real-time PCR in Applied Microbiology (Norfolk, UK: Caister Academic Press).

Gelfand, D.H. (1992). Taq DNA polymerase, PCR technology. In Principles and Applications for DNA Amplification, Erlich, H.A. ed. (Freeman and Company, New York), pp. 17-22.

Gill, P., and Ghaemi, A. (2008). Nucleic acid isothermal amplification technologies - a review. Nucleosides Nucleotides Nucleic Acids. 27, 224-243.

Goldmeyer, J., Kong, H., and Tang, W. (2007). Development of a novel one-tube isothermal reverse transcription thermophilic helicase-dependent amplification platform for rapid RNA detection. J. Mol. Diagn. 9, 639-644.

González-Escalona, N., Hammack, T.S., Russel, M., Jacobson, A.P., De Jesús, A.J., Brown, E.W., and Lampel, K.A. (2009). Detection of live Salmonella sp. cells in produce by a TaqMan-Based quantitative reverse transcriptase real-time PCR targeting invA mRNA. Appl. Environ. Microbiol. 75, 3714-3720.

Hendrix, C., Rosemeyer, H., De Bouvere, B., Van Aerschot, A., Seela, F., and Herdewijn, P. (1997). 1,5'-Anhydrohexitol oligonucleotides: hybridization and strand displacement with oligoribonucleotides, interaction with RNase $\mathrm{H}$ and HIV reverse transcriptase. Eur. J. Chem. 3, 1513-1520.

Hoorfar, J., Cook, N., Malorny, B., Wagner, M., De Medici, D., Abdulmawjood, A., and Fach, P. (2003). Making internal amplification control mandatory for diagnostic PCR. J. Clin. Microbiol. 41, 5835.

Hoorfar, J., Cook, N., Malorny, B., Wagner, M., De Medici, D., Abdulmawjood, A., and Fach, P. (2004). Diagnostic PCR: making internal amplification control mandatory. Lett. Appl. Microbiol. 38, 79-80.

Hyrup, B., and Nielson, P.E. (1996). Peptide nucleic acids (PNA): synthesis, properties and nucleic acids, a new promising antisense construct. Bioorg. Med. Chem. 4, 5-23.

Johnson, M.P., Haupt, L.M., and Griffiths, L.R. (2004). Locked nucleic acids (LNA) single nucleotide polymorphism (SNP) genotype analysis and validation using real-time PCR. Nucleic Acids Res. 32, e55.

Joneja, A., and Huang, X. (2011). Linear nicking endonuclease-mediated strand displacement DNA amplification, Anal. Biochem. 414, 58-69.

Kermekchiev, M.B., Kirilova, L.I., Vail, E.E., and Barnes, W.M. (2009). Mutants of Taq DNA polymerase resistant to PCR inhibitors allow DNA amplification from whole blood and crude soil samples. Nucleic Acids Res. 37, e40
Kiesling, T., Cox, K., Davidson, E.A., Dretchen, K., Grater, G., Hibbard, S., Lasken, R.S., Leshin, J., Skowronski, E., and Danielsen, M. (2007). Sequence specific detection of DNA using nicking endonuclease signal amplification (NESA). Nucleic Acids Res. 35, e117.

Latorra, D., Campbell, K., Wolter, A., and Hurley, J.M. (2003). Enhanced allele-specific PCR discrimination in SNP genotyping using $3^{\prime}$ locked nucleic acid (LNA) primers. Hum. Mut. 22, 79-85.

Lorenz, M.G., and Wackernagel, W. (1987). Adsorption of DNA to sand and variable degradation rates of adsorbed DNA. Appl. Environ. Microbiol. 53, 2948-2952.

Mahalanabis M., Do, J., Al-Muayad H., Zhang, J.Y., and Klapperich, C.M. (2010). An integrated disposable device for DNA extraction and helicase dependent amplification. Biomed. Microdev. 12, 353-359.

Moran, M.A., Torsvik, V.L., Torsvik, T., and Hodson, R.E. (1993). Direct extraction and purification of rRNA for ecological studies. Appl. Environ. Microbiol. 59, 915-918.

Moreau, V., Voirin, E., Paris, C., Kotera, M., Nothisen, M., Rémy, J.S., Behr, J.P., Erbacher, P., and LenneSamuel, N. (2009). Zip Nucleic Acids: new high affinity oligonucleotides as potent primers for PCR and reverse transcription. Nucleic Acids Res. 37, e130.

Nielson, P.E., and Haaima, G. (1997). Peptide nucleic acid (PNA): A DNA mimic with a pseudopeptide backbone. Chem. Soc. Rev. 26, 73-78.

Nolte, F.S. (2004). Novel internal controls for real-time PCR assays. Clin. Chem. 50, 801-802.

Nordstrom, J.L, Vickery, M.C, Blackstone, G.M., Murray, S.L., and DePaola, A. (2007). Development of a multiplex real-time PCR assay with an internal amplification control for the detection of total and pathogenic Vibrio parahaemolyticus bacteria in oysters. Appl. Environ. Microbiol. 73, 5840-5847.

Obika, S., Nanbu, D., Hari, Y., Andoh, J-i., Morio, K-i., Doi, T., and Imanishi, T. (1998). Stability and structural features of the duplexes containing nulcoeside analogs with a fixed N-type conformation. 2'-O, 4'-C methylene ribonucleosides. Tetrahedron Lett. 39, 5401-5404.

Oikonomou, I., Halatsi, K., and Kyriacou, A. (2008). Selective PCR: a novel internal amplification control strategy for enhanced sensitivity in Salmonella diagnosis. Lett. Appl. Microbiol. 46, 456-461.

Schaerli Y., Stein, V., Spiering, M.M., Benkovic, S.J., Abell, C., and Hollfelder, F. (2010). Isothermal DNA amplification using the T4 replisome: circular nicking endonucleasedependent amplification and primase-based wholegenome amplification. Nucleic Acids Res. 38, e201.

Schulz, R.G., and Gryaznov, S.M. (1996). Oligo-2'-fluoro-2'deoxynucleotide N3'->P5' phosphoramidates: synthesis and properties. Nucleic Acids Res. 24, 2966-2973.

Scipioni, A., Bourgot, I., Mauroy, A., Ziant, D., Saegerman, C., Daube, G., and Thiry, E. (2008). Detection and quantification of human and bovine noro viruses by a TaqMan RT-PCR assay with a control for inhibition. Mol. Cell. Probes 22, 215-222.

Simeonov, A., and Nikiforov, T.T. (2002). Single nucleotide polymorphism genotyping using short, fluorescently labeled locked nucleic acid (LNA) probes and fluorescence polarization detection. Nucleic Acids Res. 30, e91.

Singh, S.K., Nielsen, P., Koshkin, A.A., and Wengel, J. (1998). LNA (locked nucleic acids): synthesis and high 
affinity nucleic acid recognition. Chem. Commun. 4, 455456.

Suslov, O., and Steindler, D.A. (2005). PCR inhibition by reverse transcriptase leads to an overestimation of amplification efficiency. Nucleic Acids Res. 33, e181.

Tan, E., Erwin, B., Dames, S., Ferguson, T., Buechel, M., Irvine, B., Voelkerding, K., and Niemz, A. (2008). Specific versus nonspecific isothermal DNA amplification through thermophilic polymerase and nicking enzyme activities. Biochem. 47, 9987-9999.

Tong, Y., Tang, W., Kim, H.J., Pan, X., Ranalli, T., and Kong, H. (2008). Development of isothermal TaqMan assays for detection of biothreat organisms. Biotechniques 45 , 543-557.
Ugozzoli, L.A., Latorra, D., Pucket, R., Arar, K., and Hamby, K. (2004). Real-time genotyping with oligonucleotide probes containing locked nucleic acids. Anal. Biochem. 324, 143-152.

Van Aerschot, A., Verheggen, I., Hendrix, C., and Herdewijn, P. (1995). 1,5-Anhydrohexitol nucleic acids, a new promising antisense construct. Angew Chem. Int. Ed. 34, 1338-1339.

Vincent, M., Xu, Y., and Kong, H. (2004). Helicasedependent isothermal DNA amplification. EMBO Rep. 5, 795-800.

Voirin, E., Behr, J.P., and Kotera, M. (2007). Versatile synthesis of oligodeoxyribonucleotide-oligospermine conjugates. Nature Prot. 2, 1360-1367. 


\section{Further Reading}

Caister Academic Press is a leading academic publisher of advanced texts in microbiology, molecular biology and medical research. Full details of all our publications at caister.com

- MALDI-TOF Mass Spectrometry in Microbiology Edited by: M Kostrzewa, S Schubert (2016) www.caister.com/malditof

- Aspergillus and Penicillium in the Post-genomic Era Edited by: RP Vries, IB Gelber, MR Andersen (2016) www.caister.com/aspergillus2

- The Bacteriocins: Current Knowledge and Future Prospects Edited by: RL Dorit, SM Roy, MA Riley (2016)

www.caister.com/bacteriocins

- Omics in Plant Disease Resistance Edited by: V Bhadauria (2016) www.caister.com/opd

- Acidophiles: Life in Extremely Acidic Environments Edited by: R Quatrini, DB Johnson (2016) www.caister.com/acidophiles

- Climate Change and Microbial Ecology: Current Research and Future Trend

Edited by: J Marxsen (2016)

www.caister.com/climate

- Biofilms in Bioremediation: Current Research and Emerging Technologies

Edited by: G Lear (2016)

www.caister.com/biorem

- Microalgae: Current Research and Applications Edited by: MN Tsaloglou (2016) www.caister.com/microalgae

- Gas Plasma Sterilization in Microbiology: Theory, Applications, Pitfalls and New Perspectives Edited by: H Shintani, A Sakudo (2016) www.caister.com/gasplasma

- Virus Evolution: Current Research and Future Directions Edited by: SC Weaver, M Denison, M Roossinck, et al. (2016) www.caister.com/virusevol

- Arboviruses: Molecular Biology, Evolution and Control Edited by: N Vasilakis, DJ Gubler (2016) www.caister.com/arbo

- Shigella: Molecular and Cellular Biology Edited by: WD Picking, WL Picking (2016) www.caister.com/shigella

-Aquatic Biofilms: Ecology, Water Quality and Wastewater Treatment

Edited by: AM Romaní, H Guasch, MD Balaguer (2016)

www.caister.com/aquaticbiofilms

- Alphaviruses: Current Biology

Edited by: S Mahalingam, L Herrero, B Herring (2016)

www.caister.com/alpha

- Thermophilic Microorganisms

Edited by: F Li (2015)

www.caister.com/thermophile
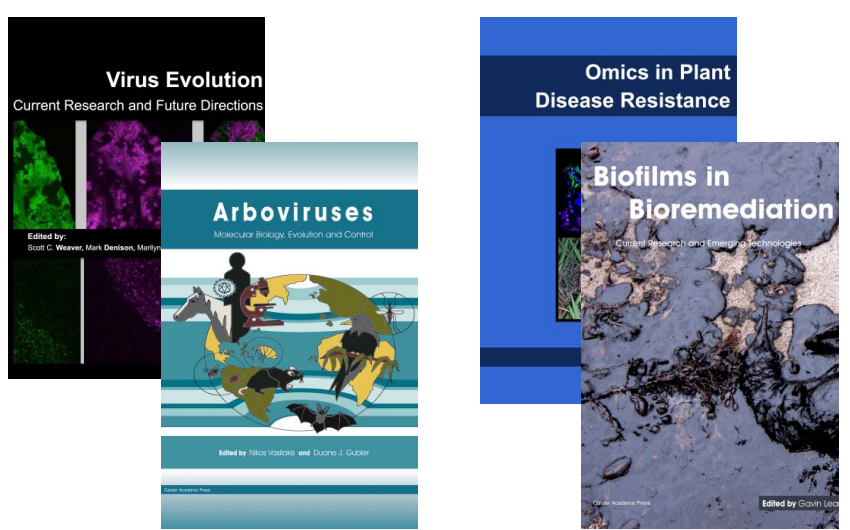
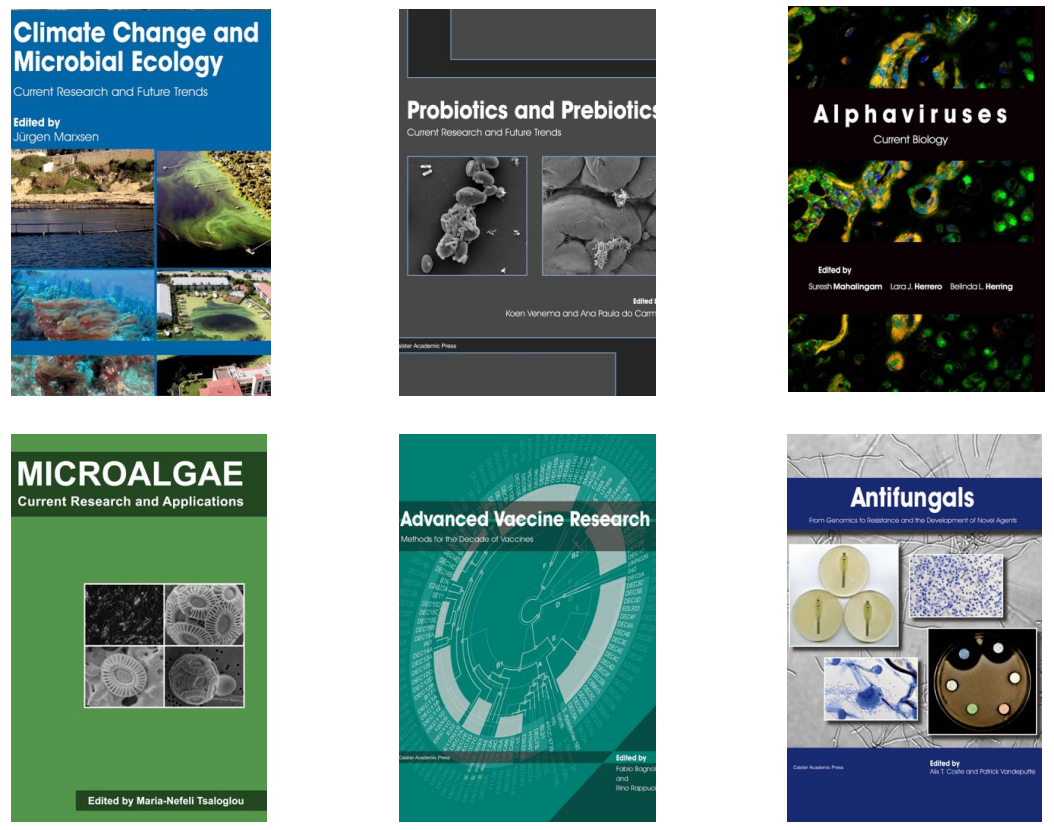

- Flow Cytometry in Microbiology: Technology and Applications Edited by: MG Wilkinson (2015) www.caister.com/flow

- Probiotics and Prebiotics: Current Research and Future Trends Edited by: K Venema, AP Carmo (2015) www.caister.com/probiotics

- Epigenetics: Current Research and Emerging Trends Edited by: BP Chadwick (2015) www.caister.com/epigenetics2015

- Corynebacterium glutamicum: From Systems Biology to Biotechnological Applications

Edited by: A Burkovski (2015)

www.caister.com/cory2

- Advanced Vaccine Research Methods for the Decade of Vaccines

Edited by: F Bagnoli, R Rappuoli (2015)

www.caister.com/vaccines

- Antifungals: From Genomics to Resistance and the Development of Novel Agents

Edited by: AT Coste, P Vandeputte (2015)

www.caister.com/antifungals

- Bacteria-Plant Interactions: Advanced Research and Future Trends Edited by: J Murillo, BA Vinatzer, RW Jackson, et al. (2015) www.caister.com/bacteria-plant

\section{- Aeromonas}

Edited by: J Graf (2015)

www.caister.com/aeromonas

- Antibiotics: Current Innovations and Future Trends

Edited by: S Sánchez, AL Demain (2015)

www.caister.com/antibiotics

- Leishmania: Current Biology and Contro Edited by: S Adak, R Datta (2015) www.caister.com/leish2

- Acanthamoeba: Biology and Pathogenesis (2nd edition) Author: NA Khan (2015)

www.caister.com/acanthamoeba2

- Microarrays: Current Technology, Innovations and Applications Edited by: Z He (2014)

www.caister.com/microarrays2

- Metagenomics of the Microbial Nitrogen Cycle: Theory, Methods and Applications

Edited by: D Marco (2014)

www.caister.com/n2 